\title{
Relationship between Physical Parameters of Various Metal Ions and Binding Affinity for Alginate
}

\author{
Yoko Idota, ${ }^{a}$ Yumi Kogure, ${ }^{a}$ Takako Kato, ${ }^{a}$ Kentaro Yano, ${ }^{a}$ Hiroshi Arakawa, ${ }^{a, b}$ \\ Chihiro Miyajima, ${ }^{c}$ Fumiyoshi Kasahara, ${ }^{c}$ and Takuo Ogihara*, \\ ${ }^{a}$ Faculty of Pharmacy, Takasaki University of Health and Welfare; 60 Nakaorui-machi, Takasaki, Gunma 370-0033, \\ Japan: ${ }^{b}$ Faculty of Pharmacy, Institute of Medical, Pharmaceutical and Health Sciences, Kanazawa University; \\ Kakuma-machi, Kanazawa, Ishikawa 920-1192, Japan: and ${ }^{c}$ Kimica Corporation; 2-4-1 Yaesu, Chuo-ku, Tokyo \\ 104-0028, Japan.
}

Received February 9, 2016; accepted July 26, 2016

We investigated the relationship between the physical parameters of various metal ions, including toxic metal ions, and the binding affinity of these metal ions for alginate (Alg). The binding constant, $K$, of $^{2+}$ was the highest among all tested metal ions. The order of $K$ values was: $\mathrm{Sr}^{2+}>\mathbf{P b}^{2+}>\mathbf{T b}^{3+}>\mathrm{Dy}^{3+}>\mathrm{Ca}^{2+}>\mathrm{Cd}^{2+}>$ $\mathrm{Mg}^{2+}>\mathrm{Fe}^{2+}>\mathrm{Fe}^{3+}>\mathrm{Co}^{2+}>\mathrm{Al}^{3+}>\mathrm{Ni}^{2+}>\mathrm{Cs}^{+}>\mathrm{Cu}^{2+}>\mathrm{Ag}^{+}>\mathrm{Li}^{+}>\mathrm{K}^{+}$. The metal ions showing the highest $\mathrm{K}$ values had ionic radii within the range of about $90-120 \mathrm{pm}$. Moreover, the $K$ values of divalent or trivalent metal ions tended to be higher than those of monovalent ions. The number of binding sites per $1 \mathrm{mg}$ of Alg (n) was highest for $\mathrm{K}^{+}$, followed by $\mathrm{Pb}^{2+}$ and $\mathrm{Cs}^{+}$. The order of affinity (calculated as the product of $n$ and $\mathrm{K}$ ) was $\mathrm{Pb}^{2+}>\mathrm{Dy}^{3+}>$ $\mathrm{Tb}^{3+}>\mathrm{Sr}^{2+}>\mathrm{Ca}^{2+}>\mathrm{Mg}^{2+}>\mathrm{Cd}^{2+}>\mathrm{Fe}^{2+}, \mathrm{Fe}^{3+}>\mathrm{Cs}^{+}>\mathrm{Al}^{3+}>\mathrm{Co}^{2+}>\mathrm{Ni}^{2+}>\mathrm{Cu}^{2+}>\mathrm{Ag}^{+}>\mathrm{K}^{+}>\mathrm{Li}^{+}$. Our results support the idea that Alg would be effective as an excretion accelerator and/or absorption inhibitor for various toxic metal ions.

Key words alginate; toxic metal; binding mechanism; affinity

Metal ions absorbed via the intestinal tract, respiratory system or skin can cause serious damage to various internal organs, depending on their type and amount. For example, lead $(\mathrm{Pb})$ causes acute damage to the central nervous system, and chronic damage to the kidney and hematopoetic and nervous systems. ${ }^{1,2)}$ Long-term, low-dose exposure to cadmium (Cd) damages the lung (chronic bronchitis, fibrosis, emphysema), kidney (renal tubular degeneration, interstitial inflammation, fibrosis, diabetes, proteinuria), and bone (fake fracture, osteomalacia). ${ }^{3)}$ Cadmium is well known to induce itai-itai disease (kidney tubular damage and osteomalacia), ${ }^{4)}$ and moreover, it is carcinogenic. ${ }^{3,5)}$ In addition, aluminum (Al) causes encephalopathy and osteodystrophy, ${ }^{6,7)}$ and copper $(\mathrm{Cu})$ causes hemolytic anemia and gastroenteritis. ${ }^{8)}$ In the case of acute oral exposure, damage can be reduced by immediate treatments such as induction of vomiting and/or the use of a laxative to promote excretion of the metal. In addition, chelating agents can be administered; for example, ethylenediaminetetraacetic acid and dimercaptopropionylsulfonate are used as antidotes for $\mathrm{Pb}$ poisoning, ${ }^{9-11)}$ and dimercaprol is used for detoxification of $\mathrm{Pb}$ and $\mathrm{Cu} .^{11,12)}$ However, in the case of chronic exposure, it is essential to use intrinsically safe absorption inhibitors and/or excretion accelerators that are suitable for long-term administration.

Alginate (Alg), an intercellular polysaccharide found in brown algae, is used as a health food and food additive to reduce cholesterol in the blood and to inhibit weight gain. ${ }^{13-15)}$ It also protects the gastric mucous membrane. ${ }^{16)}$ Moreover, it was reported that accumulation of strontium $(\mathrm{Sr})$ in the human body decreased when sodium alginate (Na-Alg) was ingested before exposure to $\mathrm{Sr}^{17)}$ Further, when rats pre-fed with NaAlg for ten days were administered $\mathrm{Sr}$, the cumulative amount of $\mathrm{Sr}$ in the body was markedly reduced, compared with the control group. ${ }^{18)}$ Consequently, it has been suggested that daily intake of $\mathrm{Na}-\mathrm{Alg}$ would offer protection against radiation damage from radioactive fall-out by decreasing the absorption of radioactive Sr. Accordingly, the International Atomic Energy Agency (IAEA) has recommended Na-Alg intake for persons exposed to large amounts of radioactive $\mathrm{Sr}^{19)}$

We have compared the effects of $\mathrm{Na}-\mathrm{Alg}$ and $\mathrm{Ca}-\mathrm{Alg}$ in promoting excretion and decreasing absorption of $\mathrm{Sr}$ and cesium (Cs) in rats. ${ }^{20)}$ Both additives increased the excretion of $\mathrm{Sr}$, though Cs concentration was significantly reduced only in the Ca-Alg group. There have been some reports describing the capacity of Alg for metal binding and the order of affinity between Alg and metals. ${ }^{21,22)}$ However, there is little information about the relationship between the physical parameters of various metal ions and the binding affinity of these metal ions for Alg. Therefore we performed range and limitation tests of the adapting metals by evaluating the binding constants and the binding amount with Alg using several metal ions in this paper. Moreover, we investigated the relationship between the charge number and the radius of the metals, and their binding affinity. In addition, terbium $\left(\mathrm{Tb}^{3+}\right)$ and dysprosium $\left(\mathrm{Dy}^{3+}\right)$ were added as trivalent metal ions to maintain the variation of physical parameters, especially ionic charges and radius.

\section{MATERIALS AND METHODS}

Chemicals Na-Alg (high-molecular-weight, rich in guluronic acid) was supplied by Kimica Corporation (Tokyo, Japan). Chlorides of strontium $\left(\mathrm{Sr}^{2+}\right)$, lead $\left(\mathrm{Pb}^{2+}\right), \mathrm{Tb}^{3+}, \mathrm{Dy}^{3+}$, calcium $\left(\mathrm{Ca}^{2+}\right)$, cadmium $\left(\mathrm{Cd}^{2+}\right)$, magnesium $\left(\mathrm{Mg}^{2+}\right)$, iron(II) $\left(\mathrm{Fe}^{2+}\right)$, iron(III) $\left(\mathrm{Fe}^{3+}\right)$, cobalt $\left(\mathrm{Co}^{2+}\right)$, aluminium $\left(\mathrm{Al}^{3+}\right)$, nickel $\left(\mathrm{Ni}^{2+}\right)$, cesium $\left(\mathrm{Cs}^{+}\right)$, copper $\left(\mathrm{Cu}^{2+}\right)$, silver $\left(\mathrm{Ag}^{+}\right)$, lithium $\left(\mathrm{Li}^{+}\right)$, potassium $\left(\mathrm{K}^{+}\right)$were obtained from Wako Pure Chemical Industries, Ltd. (Osaka, Japan). All other chemicals and solvents were analytical-grade commercial products. 
Binding Experiments We performed binding experiments according to the method previously reported. ${ }^{20)}$ Aqueous solutions of a metal salt $(0,0.6,2,6$ or $20 \mathrm{~mm})$ and an equivalent amount containing Na-Alg $(2 \mathrm{mg} / \mathrm{mL})$ were mixed. The initial concentrations of the metal ions were set at $0,0.3$, 1,3 or $10 \mathrm{~mm}$. The mixed solutions $(0.5 \mathrm{~mL})$ were incubated at room temperature for $30 \mathrm{~min}$, and then passed through an Amicon Ultra 3k (Merck Millipore, Darmstadt, Germany) at $15000 \times \boldsymbol{g}$ for $20 \mathrm{~min}$. The amount of unbound metal in the filtrate was determined using an atomic absorption photometer (ContrAA ${ }^{\circledR} 700$, Analytik Jena AG, Jena, Germany). The amount of bound metal ion was calculated from the amount of unbound metal ion remaining. Data are expressed as the mean \pm standard deviation (S.D.). The binding constants $(K$, $\left.\mathrm{mM}^{-1}\right)$ and the number of binding sites per $1 \mathrm{mg}$ of $\mathrm{Alg}(n$, $\mu \mathrm{mol} / \mathrm{mg}$ Alg) were analyzed using double-reciprocal plots. Finally, the affinity of each metal ion for Alg was calculated by multiplying the $n$ and $K$ values.

\section{RESULTS AND DISCUSSION}

The relationship between the initial concentration of metal ion and the amount of bound metal ion was examined. The case of $\mathrm{Sr}^{2+}$ is shown in Fig. 1 as a typical example. The amount of bound metal ion initially increased concentrationdependently, and was saturated at higher concentrations. The $K$ and $n$ values for $\mathrm{Sr}^{2+}$, calculated from the double-reciprocal plot, were $2046.1 \mathrm{~mm}^{-1}$ and $1.52 \mu \mathrm{mol} / \mathrm{mg} \mathrm{Alg}$, respectively (Fig. 1b). Therefore, the affinity $(n \times K)$ between $\mathrm{Alg}$ and $\mathrm{Sr}^{2+}$ was calculated as $3115 \mathrm{~mL} / \mathrm{mg}$ Alg (Fig. 1a).

The values of $K, n$ and affinity for all tested metal ions are listed in Table 1. Among them, $\mathrm{Sr}^{2+}$ showed the highest $K$ value, followed by $\mathrm{Pb}^{2+}, \mathrm{Tb}^{3+}$ and $\mathrm{Dy}^{3+}$. The order of $K$ values was as follows: $\mathrm{Sr}^{2+}>\mathrm{Pb}^{2+}>\mathrm{Tb}^{3+}>\mathrm{Dy}^{3+}>\mathrm{Ca}^{2+}>\mathrm{Cd}^{2+}>\mathrm{Mg}^{2+}>$ $\mathrm{Fe}^{2+}>\mathrm{Fe}^{3+}>\mathrm{Co}^{2+}>\mathrm{Al}^{3+}>\mathrm{Ni}^{2+}>\mathrm{Cs}^{+}>\mathrm{Cu}^{2+}>\mathrm{Ag}^{+}>\mathrm{Li}^{+}>\mathrm{K}^{+}$.

The relationship among $K$ value, charge number and ionic radius is shown in Fig. 2. The metal ions showing the highest $K$ values had ionic radii within the range of about $90-120 \mathrm{pm}$. (a)

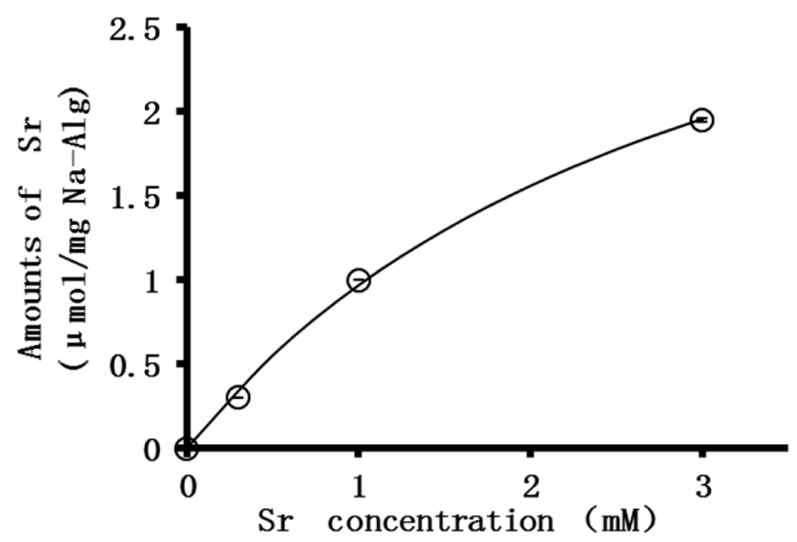

(b)

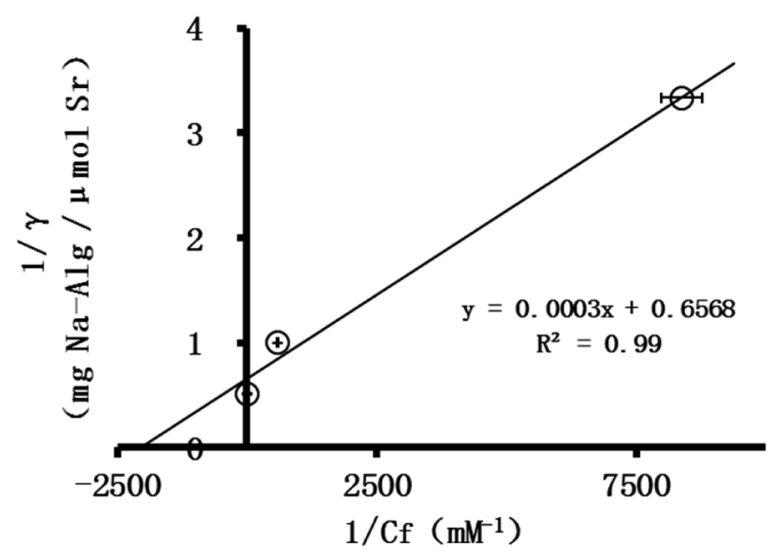

Fig. 1. The Relationship between Initial Concentration of $\mathrm{Sr}^{2+}$ and the Amount of $\mathrm{Sr}^{2+}$ Bound with Na-Alg

The data are the mean \pm S.D. $(n=6)$. (a) Normal plot. (b) Double reciprocal plot $C_{\mathrm{f}}$, concentration of unbound metal (mM); $\gamma$, concentration of bound metal $(\mu \mathrm{mol}$ metal/mg Na-Alg).

Table 1. Values of $K, n$ and Affinity for All Tested Metal Ions

\begin{tabular}{|c|c|c|c|c|c|}
\hline Metal & Symbol & $\begin{array}{c}\text { Charge number } \\
(+)\end{array}$ & $\begin{array}{c}\text { Number of binding sites } \\
n \\
(\mu \mathrm{mol} / \mathrm{mg}-\mathrm{Alg})\end{array}$ & $\begin{array}{c}\text { Binding constant } \\
K \\
\left(\mathrm{mM}^{-1}\right)\end{array}$ & $\begin{array}{c}\text { Affinity } \\
n K \\
(\mathrm{~mL} / \mathrm{mg}-\mathrm{Alg})\end{array}$ \\
\hline Strontium & $\mathrm{Sr}$ & 2 & 1.52 & 2046.1 & 3115 \\
\hline Lead & $\mathrm{Pb}$ & 2 & 3.59 & 1906.5 & 6849 \\
\hline Terbium & $\mathrm{Tb}$ & 3 & 1.8 & 1769 & 3184 \\
\hline Dysprosium & Dy & 3 & 1.9 & 1689.7 & 3205 \\
\hline Calcium & $\mathrm{Ca}$ & 2 & 1.25 & 779.2 & 977 \\
\hline Cadmium & $\mathrm{Cd}$ & 2 & 1.7 & 398.4 & 676 \\
\hline Magnesium & $\mathrm{Mg}$ & 2 & 1.86 & 381.9 & 710 \\
\hline Iron(II) & $\mathrm{Fe}$ & 2 & 1.4 & 376.9 & 526 \\
\hline Iron(III) & $\mathrm{Fe}$ & 3 & 1.85 & 284.1 & 526 \\
\hline Cobalt & $\mathrm{Co}$ & 2 & 1.3 & 257.2 & 334 \\
\hline Aluminium & $\mathrm{Al}$ & 3 & 2.03 & 182.9 & 371 \\
\hline Nickel & $\mathrm{Ni}$ & 2 & 1.55 & 150.3 & 233 \\
\hline Caesium & $\mathrm{Cs}$ & 1 & 3.4 & 131.8 & 448 \\
\hline Copper & $\mathrm{Cu}$ & 2 & 1.87 & 116 & 217 \\
\hline Silver & $\mathrm{Ag}$ & 1 & 1.34 & 22 & 29 \\
\hline Lithium & $\mathrm{Li}$ & 1 & 1.01 & 6.4 & 6.4 \\
\hline Potassium & $\mathrm{K}$ & 1 & 6.52 & 1.07 & 6.9 \\
\hline
\end{tabular}




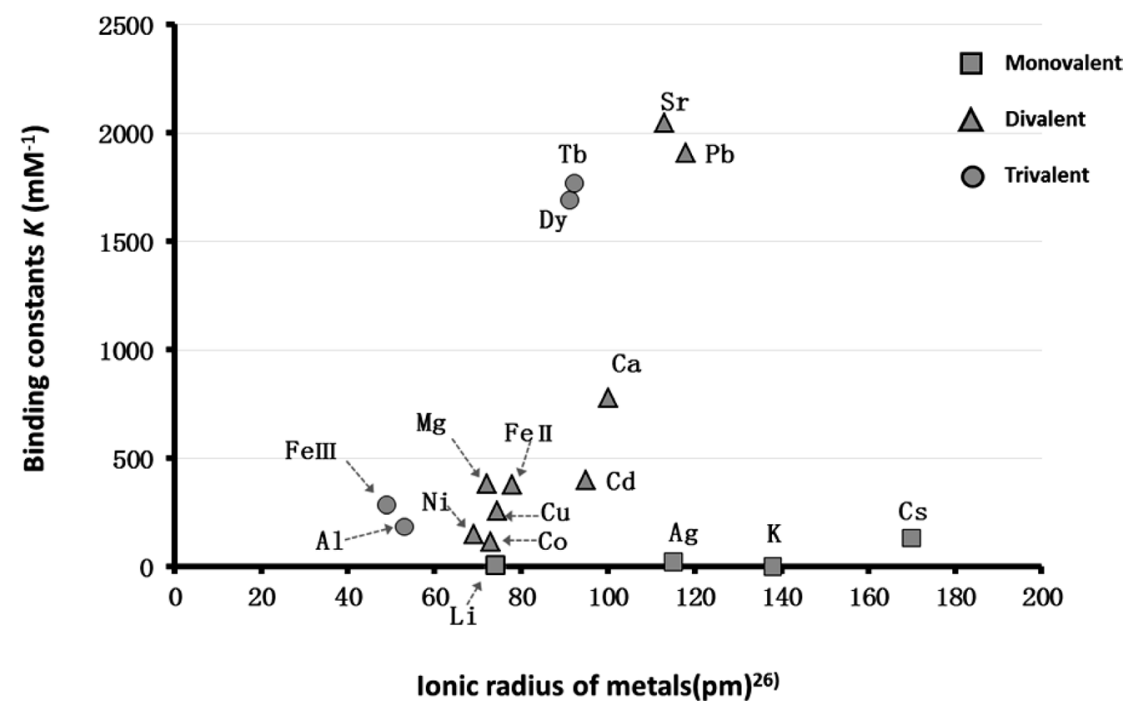

Fig. 2. The Relationships between $K$ Value, Charge Number and Ionic Radius of Metal Ions

Moreover, the $K$ values of divalent or trivalent metal ions tended to be higher than those of monovalent ions. It is well known that Alg forms a cross-linked structure with divalent or trivalent metal ions, resulting in gel formation. It appears that metal ions with an ionic radius of about $90-120 \mathrm{pm}$ form robust and water-insoluble gels, whereas, for example, divalent $\mathrm{Mg}$ ion with a smaller ionic radius forms only a loose gel with Alg.

On the other hand, the affinity, which is the product of the binding constant and the number of binding sites, is crucial for practical utilization of Alg to absorb metal ions. The number of binding sites per $1 \mathrm{mg}$ of Alg $(n)$ was highest for $\mathrm{K}^{+}$, followed by $\mathrm{Pb}^{2+}$ and $\mathrm{Cs}^{+}$, as shown in Table 1 . The calculated values of affinity $(n K$; Table 1$)$ were in the following order: $\mathrm{Pb}^{2+}>\mathrm{Dy}^{3+}>\mathrm{Tb}^{3+}>\mathrm{Sr}^{2+}>\mathrm{Ca}^{2+}>\mathrm{Mg}^{2+}>\mathrm{Cd}^{2+}>\mathrm{Fe}^{2+}$, $\mathrm{Fe}^{3+}>\mathrm{Cs}^{+}>\mathrm{Al}^{3+}>\mathrm{Co}^{2+}>\mathrm{Ni}^{2+}>\mathrm{Cu}^{2+}>\mathrm{Ag}^{+}>\mathrm{K}^{+}>\mathrm{Li}^{+}$. It is interesting that the affinity between $\mathrm{Alg}$ and $\mathrm{Cs}$ was relatively small, even though we previously showed that Ca-Alg was effective for promoting excretion and decreasing absorption of Cs in rats. ${ }^{20)}$ Not only the affinity between Alg and metals, but also other factors, such as the specific combination of Alg salt and metal ion, may influence excretion and/or absorption of individual metal ions in the presence of Alg.

People are exposed to various toxic metals in their diet and the environment on a daily basis. Trace levels of $\mathrm{Cd}$ are found in rice, a staple of the Japanese diet. ${ }^{23,24)}$ Also, $\mathrm{Pb}$ is a contaminant of various foods and food ingredients, especially vegetables. ${ }^{25}$ ) Furthermore, the Fukushima nuclear power plant accident in March 2011 resulted in the release of significant amounts of radioactive materials into the atmosphere. Human contamination from these materials, especially radioactive $\mathrm{Sr}^{2+}$ and $\mathrm{Cs}^{+}$, which have long half-lives, is considered a critical public health issue in Japan. In order to prevent bioaccumulation of such contaminants, many apparently healthy people take so-called "detox foods" on a daily basis. Our present results provide some support for this as a preventive measure. It should be noted that Alg and its salts are very safe and suitable for long-term continued ingestion; indeed, their Acceptable Daily Intake (ADI) evaluated by JECFA: FAO/ WHO Expert Committee on Food Additives is given as "Not specified."
In conclusion, our results indicate that the affinity of Alg for various metal ions is dependent upon their charge and ionic radius. Our results are consistent with the idea that Alg would be effective as an excretion accelerator and/or absorption inhibitor for various toxic metal ions, especially divalent metals such as $\mathrm{Pb}$ and $\mathrm{Cd}$. Further studies are planned along these lines.

Acknowledgment This work was supported by the Japan Society for the Promotion of Science (JSPS) Grant-in-Aid for Challenging Exploratory Research (KAKENHI) Grant Number 25560062

Conflict of Interest Chihiro Miyajima and Fumiyoshi Kasahara are employees of Kimica Corporation. The other authors have no potential conflict of interest.

\section{REFERENCES}

1) Chang LW. The neurotoxicology and pathology of organomercury, organolead, and organotin. J. Toxicol. Sci., 15 (Suppl. 4), 125-151 (1990).

2) Needleman H. Lead poisoning. Аnпu. Rev. Med., 55, 209-222 (2004).

3) WHO. Environmental Health Criteria 134: Cadmium. World Health Organization, Geneva (1992).

4) Murata I, Hirono T, Saeki Y, Nakagawa S. Cadmium enteropathy, renal osteomalacia ("Itai Itai" disease in Japan). Bull. Soc. Int. Chir., 29, 34-42 (1970).

5) Pinot F, Kreps SE, Bachelet M, Hainaut P, Bakonyi M, Polla BS. Cadmium in the environment: sources, mechanisms of biotoxicity, and biomarkers. Rev. Environ. Health, 15, 299-323 (2000).

6) Parkinson IS, Feest TG, Kerr DNS, Ward MK, Fawcett RWP. Fracturing dialysis osteodystrophy and dialysis encephalopathy. An epidemiological survey. Lancet, 24, 406-409 (1979).

7) Walker GS, Aaron JE, Peacock M, Robinson PJ, Davison AM. Dialysate aluminium concentration and renal bone disease. Kidney Int., 21, 411-415 (1982).

8) Patil M, Sheth KA, Krishnamurthy AC, Devarbhavi H. A review and current perspective on Wilson disease. J. Clin. Exp. Hepatol., 3 , 321-336 (2013).

9) Foreman H, Hardy HL, Shipman TL, Belknap EL. Use of calcium ethylenediaminetetraacetate in cases of lead intoxication. AMA 
Arch. Ind. Hyg. Occup. Med., 7, 148-151 (1953).

10) Fujii C. Antidotes for poisoning and medication overdosage. Nihon Geka Gakkai Zasshi, 101, 794-798 (2000).

11) Cao Y, Skaug MA, Andersen O, Aaseth J. Chelation therapy in intoxications with mercury, lead and copper. J. Trace Elem. Med. Biol., 31, 188-192 (2015).

12) Telfer JG. Use of BAL in lead poisoning; a preliminary report on one case. J. Am. Med. Assoc., 135, 835-837 (1947).

13) Nishizawa M, Kuda T, Yamagishi T, Tsuji K. Effect of depolymerized sodium alginate on the excretion of cholesterol from rats. $J$. Home Econ. Jpn., 48, 689-693 (1997).

14) Peters HP, Koppert RJ, Boers HM, Ström A, Melnikov SM, Haddeman E, Schuring EA, Mela DJ, Wiseman SA. Dose-dependent suppression of hunger by a specific alginate in a low-viscosity drink formulation. Obesity, 19, 1171-1176 (2011).

15) Georg Jensen M, Kristensen M, Astrup A. Effect of alginate supplementation on weight loss in obese subjects completing a 12-week energy-restricted diet: a randomized controlled trial. Am. J. Clin. Nutr., 96, 5-13 (2012).

16) Ichihashi H, Kondo T, Imamura T. Hemostasis of massive upper gastrointestinal hemorrhage by sodium alginate. J. Jpn. Soc. Clin. Surg., 40, 1169-1172 (1968).

17) Hesp R, Ramsbottom B. Effect of sodium alginate in inhibiting uptake of radiostrontium by the human body. Nature, 208, 1341-1342 (1965).

18) Nishimura Y, Wui IS, Kim KY, Watari K, Imai K, Inaba J, Matsusaka $\mathrm{N}$. Effect of chitosan and alginate on the biokinetics of radio- strontium in rats. Radioisotopes, 40, 244-247 (1991).

19) Radiation protection in the design of radiotherapy facilities. Safety Reports Series. No. 47, IAEA, Vienna (2006).

20) Idota $Y$, Harada H, Tomono T, Morimoto K, Kobayashi S, Kakinuma C, Miyajima C, Kasahara F, Ogihara T. Alginate enhances excretion and reduces absorption of strontium and cesium in rats. Biol. Pharm. Bull., 36, 485-491 (2013).

21) Haug A, Bjerrum J, Buchardt O, Olsen GE, Pedersen C, Toft J. The affinity of some divalent metals for different types of alginates. Acta Chem. Scand., 15, 1794-1795 (1961).

22) Haug A. Composition and Properties of Alginates. Report No. 30. Norwegian Inst. of Seaweed Res., Trondheim, Norway (1964).

23) Horiguchi H. Current status of cadmium exposure among Japanese, especially regarding the safety standard for cadmium concentration in rice and adverse effects on proximal renal tubular function observed in farmers exposed to cadmium through consumption of self-grown rice. Nippon Eiseigaku Zasshi, 67, 447-454 (2012).

24) Ikeda M, Shimbo S, Watanabe T, Yamagami T. Correlation among cadmium levels in river sediment, in rice, in daily foods and in urine of residents in 11 prefectures in Japan. Int. Arch. Occup. Environ. Health, 79, 365-370 (2006).

25) Teraoka H, Morii F, Kobayashi J. The concentrations of 24 elements in foodstuffs and the estimate of their daily intake. J. Jpn. Soc., Food Nutrition, 34, 221-239 (1981).

26) Shannon RD, Prewitt CT. Effective ionic radii in oxides and fluorides. Acta Crystallogr. sect. B, B25, 925-946 (1969). 